\title{
Joint cartilage thickness measured by ultrasound in juvenile idiopathic arthritis
}

\author{
D Pradsgaard ${ }^{1 *}$, AH Spannow ${ }^{2}$, CW Heuck², A Hørlyck², T Herlin² \\ From 2011 Pediatric Rheumatology Symposium sponsored by the American College of Rheumatology \\ Miami, FL, USA. 2-5 June 2011
}

\begin{abstract}
Purpose
Joint cartilage degradation is one of the early outcomes in juvenile idiopathic arthritis (JIA). One of the primary goals of rheumatic treatment is to prevent joint destruction. We therefore need sensitive methods to evaluate cartilage thickness. Ultrasonography (US) has shown to be a reliable tool in the assessment of joint cartilage in rheumatic disease. We have previously been able to establish age- and sex-related normal reference intervals for joint cartilage thickness throughout childhood ${ }^{(1)}$. The purpose of this study was to investigate: - whether US is a sensible method in the evaluation of joint cartilage in JIA patients; - US feasibility as a monitoring and prognostic tool.
\end{abstract}

\section{Methods}

In a cross-sectional study we included 49 patients diagnosed according to the 2001 revised ILAR classification of JIA. Subsets of JIA were 9 systemic onsets, 21 oligoarticular (P/E: 15/6), and 19 polyarticular (RF -/+: 14/5) JIA. The patients were all Danish Caucasians, mean age (range) 10.3 yrs (5-15), boys/girls: 17/32. A group of healthy children from a previous study [1] were used for comparison, 394 Danish Caucasians, age 10.9 (6-16), boys/girls: $217 / 177$. Patients were examined with bilateral grey-scale US of knee joint cartilage. All measurements were made twice and the average was calculated. Knee cartilage was measured on the femur at the midline of the intercondylar notch, with knee maximally flexed. Scans were based on EULAR standard scans.

\section{Results}

The age, height, and weight, did not differ between JIA subtypes and healthy children (ANOVA: $\mathrm{p}=0.4, \mathrm{p}=0.2, \mathrm{p}=$ 0.3 ). Disease duration did not differ between JIA subtypes

'Aarhus University Hospital, Skejby, Aarhus N, Region Midt, Denmark

Full list of author information is available at the end of the article $(\mathrm{p}=0.3)$. We found a significant difference in the average knee cartilage thickness between oligo- $(3.0 \mathrm{~mm} \pm 0.7)$ and poly- $(2.5 \mathrm{~mm} \pm 0.5) \mathrm{JIA}$, also when controlling for age and sex (linear regression: $\mathrm{p}<0.01$ ). There was a significant difference between healthy $(3.5 \mathrm{~mm} \pm 0.5)$ and all three JIA subgroups (Systemic onset: $2.8 \mathrm{~mm} \pm 0.6$, Oligo- $3.0 \mathrm{~mm} \pm 0.7$, Polyarticular $2.5 \mathrm{~mm} \pm 0.5$ ) when controlling for age and sex, (lin. regress: $\mathrm{p}<0.001$ for all). Knee cartilage were significantly thicker in JIA boys $(3.1 \mathrm{~mm} \pm 0.6)$ than JIA girls $(2.6 \mathrm{~mm} \pm 0.6)$ (Mann-Whitney, $\mathrm{p}<0.005))$ and in healthy boys $(3.7 \mathrm{~mm} \pm 0.5)$ compared to girls $(3.3 \mathrm{~mm} \pm 0.5)(\mathrm{p}<0.001)$. There was a significant difference between right $(2.7 \mathrm{~mm} \pm 0.6)$ and left $(2.9 \mathrm{~mm} \pm 0.7)$ side within all JIA patients(Paired t-test, $\mathrm{p}=0.01$ ), but no difference within the healthy group. Cartilage thickness decreased with increasing age in all groups, but not with increasing duration of disease.

\section{Conclusion}

We found differences in knee cartilage thickness between oligo- and polyarticular JIA and between healthy children and all three subtypes of JIA. In the present study we also found a difference between sexes as previously shown in the healthy control group ${ }^{(1)}$, but in contrast we did find a difference between right and left knee. Our results shows that US is able to assess even small changes in joint cartilage thickness, which makes it valuable in the evaluation of joint diseases in childhood.

\section{Disclosure}

D. Pradsgaard: None; A. H. Spannow: None; C. W. Heuck: None; A. Hørlyck: None; T. Herlin: None.

\footnotetext{
Author details

${ }^{1}$ Aarhus University Hospital, Skejby, Aarhus N, Region Midt, Denmark. ${ }^{2}$ Aarhus $\mathrm{N}$, Region Midt, Denmark.
}

Published: 13 July 2012 


\section{Reference}

1. Spannow A, et al: Ultrasonographic measurements of joint cartilage thickness in healthy children: age- and sex-related standard reference values. J Rheumatol 2010, 37:2595-2601.

doi:10.1186/1546-0096-10-S1-A35

Cite this article as: Pradsgaard et al:: Joint cartilage thickness measured by ultrasound in juvenile idiopathic arthritis. Pediatric Rheumatology 2012 10(Suppl 1):A35.

Submit your next manuscript to BioMed Central and take full advantage of:

- Convenient online submission

- Thorough peer review

- No space constraints or color figure charges

- Immediate publication on acceptance

- Inclusion in PubMed, CAS, Scopus and Google Scholar

- Research which is freely available for redistribution

Submit your manuscript at www.biomedcentral.com/submit
Ciomed Central 